\title{
Antimicrobial Activities of Some Synthetic Flavonoids
}

\author{
Nazifi Saleh Ibrahim ${ }^{1,2} *$ And Farediah Ahmed ${ }^{2}$ \\ 1. Department of Chemistry, Faculty of Science, Bayero University Kano, Nigeria \\ 2. Department of Chemistry, Faculty of Science, University Teknologi Malaysia, 81310 Skudai, Johor, Malaysia.
}

\begin{abstract}
In an attempt to study the biological activities of flavonoids, a flavone, flavanone and series of chalcones were synthesized and characterized by $I R$ and ${ }^{l} H$ NMR and elemental analysis. All the targeted compounds were screened for their antibacterial activity against Bacillus cereus, Enterococcus faecalis, Kleibsiella pneumonia and Pseudomonas aeroginosa and antifungal activity against Aspergillus fumigatus and Candida glabrata. Only 2'-hydroxy-4-chlorochalcone (3) and 2'-hydroxy-4-nitrochalcone (4) showed moderate antimicrobial activity against the Gram-positive bacteria with MIC $125 \mu \mathrm{g} / \mathrm{ml}$ and a very weak antifungal activity with MIC $250 \mu \mathrm{g} / \mathrm{ml}$. All other compounds displayed very weak activities against all the tested microorganisms.
\end{abstract}

Keywords: Flavonoids, Chalcones, Flavone, Flavanone, antibacterial and antifungal.

\section{Introduction}

Antimicrobial is a general term for natural or synthetic compounds which at certain concentrations inhibit the growth of or kill microorganisms completely. The term antimicrobials are collective for antiviral, antibacterial, antifungal and antiprotozoal. Due to the rapid development of microorganism's resistance to antimicrobial agents, it is necessary to discover compounds both naturally and synthetic of the new antimicrobial agents to help in the battle against pathogenic microorganisms. Much research has been carried out with the aim to discover the therapeutic values of flavonoid derivatives.

Flavonoids are poly-phenolic compounds that are ubiquitous in nature and have been reported to possess various biological activities some of which include; antimicrobial, antioxidant, antimalarial, cytotoxic, antidepressant, anti-inflammatory, anti HIV and anticancer [1-7]. Scientific studies involving pharmaceutical drug potencies of flavonoids are extensively examined in the past several years and are increasing [8]. Chalcones been the precursors of various biologically important heterocyclic compounds have a reactive $\alpha, \beta$-unsaturated carbonyl group which was found to be responsible for their antimicrobial activities. The antimicrobial activities may be altered depending on the type and position of the substituent(s) on the aromatic rings [9]. Despite the successful report on the targeted compounds, their effect on the antibacterial and antifungal activities against the tested microorganisms has not been reported. However, this study focuses on the synthesis and biological evaluation of the compounds as antibacterial and antifungal agents and also the effect of the substituents on aromatic rings against the tested microorganisms.

\section{Experimental}

The melting points of the target compounds were measured and recorded using Leica Galen III Kofler micro melting points apparatus and were uncorrected. The ${ }^{1} \mathrm{H}(400 \mathrm{MHz})$ NMR experiments were recorded Chloroform $\left(\mathrm{CDCl}_{3}\right.$, purity $\left.99.96 \%\right)$ on a Bruker Avance spectrometer with referenced against residual nondeuterated solvent $\left[{ }^{1} \mathrm{H}\right.$ NMR, $\left.\mathrm{CDCl}_{3}(7.27 \mathrm{ppm})\right]$. Meanwhile, the Infrared (IR) was recorded on Perkin Elmer 1650 FTIR spectrophotometer as thin film $\mathrm{KBr}$ pellet for solid samples.

\section{General Procedure for the preparation of Chalcones}

A mixture of substituted acetophenone $(0.01 \mathrm{~mole})$ and substituted benzaldehyde $(0.01 \mathrm{~mole})$ was stirred in ethanol and then sodium hydroxide solution (50\%) was added till highly turbid solution was obtained. Completion of mixture was monitored by TLC. The mixture was kept overnight at room temperature and it was poured on crush ice and acidified with dilute hydrochloric acid. The precipitate obtained was washed with ethanol and purified by chromatographic technique and recrystallization from ethanol [10].

\section{General Procedure for the preparation of Flavone}

A mixture of substituted chalcone $(0.01 \mathrm{~mol})$ and $\mathrm{I}_{2}(0.0078 \mathrm{mmol})$ in DMSO $(6 \mathrm{ml})$ were refluxed for 45 mins and monitored using TLC. Water was added to cooled mixture and extracted with EtOAc. The organic extract was then washed with saturated $\mathrm{NaS}_{2} \mathrm{O}_{3}$ solution, followed by water and brine. It was then dried over $\mathrm{MgSO}_{4}$, filtered and evaporated under reduced pressure. The resulting solid was then re-crystallized from ethanol to yield substituted flavone [11]. 


\section{General Procedure for the preparation of Flavanone}

A mixture of susbstituted chalcone $(0.01 \mathrm{~mol}), \mathrm{MeOH}(30 \mathrm{~mL})$ and $10 \% \mathrm{HCl}(5 \mathrm{ml})$ was refluxed for 60 mins. NaOAc was added to the mixture and further refluxed for $48 \mathrm{hrs}$. The progress of the reaction was monitored by TLC. Water was added to the cooled mixture and the organic layer was extracted with EtOAc, dried using $\mathrm{MgSO}_{4}$, filtered and evaporated under reduced pressure. The residual yellow oil was purified using silica gel CC to afford substituted flavanone [12].

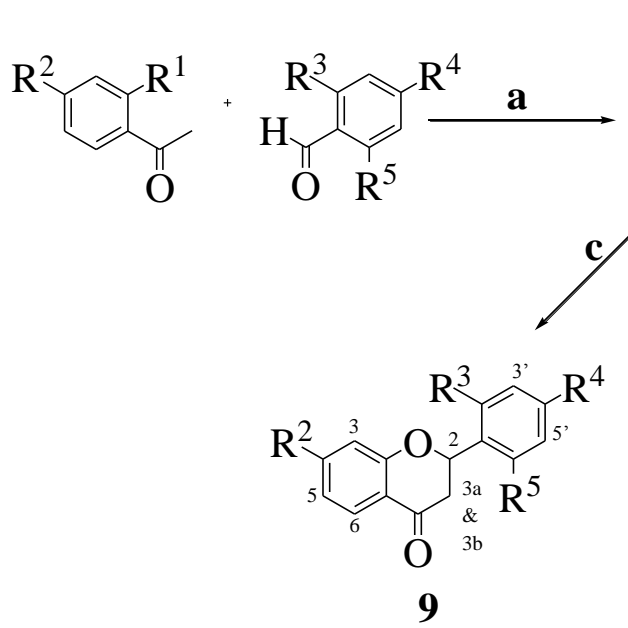

1. $\mathrm{R}^{1}=\mathrm{R}^{4} \mathrm{H}, \mathrm{R}^{2}=\mathrm{OH}, \mathrm{R}^{3}=\mathrm{R}^{5}=\mathrm{Cl}$

4. $\mathrm{R}^{1}=\mathrm{OH}, \mathrm{R}^{2}=\mathrm{R}^{3}=\mathrm{R}^{5}=\mathrm{H}, \mathrm{R}^{4}=\mathrm{NO}_{2}$

2. $\mathrm{R}^{1}=\mathrm{OH}, \mathrm{R}^{2}=\mathrm{R}^{4}=\mathrm{H}, \mathrm{R}^{3}=\mathrm{R}^{4}=\mathrm{Cl}$

5. $\mathrm{R}^{1}=\mathrm{OH}, \mathrm{R}^{2}=\mathrm{R}^{3}=\mathrm{R}^{5}=\mathrm{H}, \mathrm{R}^{4}=\mathrm{NMe}_{2}$

7. $\mathrm{R}^{1}=\mathrm{OH}, \mathrm{R}^{2}=O$-prenyl, $\mathrm{R}^{3}=\mathrm{R}^{5}=\mathrm{Cl}, \mathrm{R}^{4}=\mathrm{H} \quad$ 8. $\mathrm{R}^{2}=\mathrm{R}^{4}=\mathrm{H}, \mathrm{R}^{3}=\mathrm{R}^{5}=\mathrm{Cl}$<smiles>[R]c1ccc(C(=O)C=Cc2c([R])cc([R])cc2[R])c([R])c1</smiles>

$1-7$<smiles>[R]c1cc([R])c(-c2cc(=O)c3ccc([R])cc3o2)c([R])c1</smiles>

3. $\mathrm{R}^{1}=\mathrm{OH}, \mathrm{R}^{2}=\mathrm{R}^{3}=\mathrm{R}^{5}=\mathrm{H}, \mathrm{R}^{4}=\mathrm{Cl}$ 6. $\mathrm{R}^{1}=\mathrm{OH}, \mathrm{R}^{2}=\mathrm{R}^{3}=\mathrm{R}^{5}=\mathrm{H}, \mathrm{R}^{4}=\mathrm{OMe}$

9. $\mathrm{R}^{2}=\mathrm{R}^{4}=\mathrm{H}, \mathrm{R}^{3}=\mathrm{R}^{5}=\mathrm{Cl}$

Scheme 1: Synthesis of chalcones, flavone and flavanone derivative. (a): NaOH, Eaton, stir 24 hrs; (b): $\mathrm{I}_{2}$, DMSO, reflux 2 hrs and (c): (i): $10 \% \mathrm{HCl}, \mathrm{MeOH}$, reflux 60 mins; (ii): $\mathrm{NaOAc}$, reflux 48 hrs.

\section{Characterization of the Synthesized compounds}

4'-Hydroxy-2,6-dichlorochalcone (1)

IR $\left(v \mathrm{~cm}^{-1}\right): 3340(-\mathrm{OH}), 1654(\mathrm{C}=\mathrm{O}), 1613(\mathrm{C}=\mathrm{C}$ alkene $), 1599$ and $1566(\mathrm{C}=\mathrm{C}$ aromatic $), 1226(\mathrm{C}-\mathrm{O})$ and 770 $(\mathrm{C}-\mathrm{Cl}) ;{ }^{1} \mathrm{H}$ NMR $\left(400 \mathrm{MHz}, \mathrm{CDCl}_{3}\right): \delta 6.96\left(2 \mathrm{H}, \mathrm{d}, J=8.4 \mathrm{~Hz}, \mathrm{H}-3^{\prime}\right.$ and $\left.\mathrm{H}-5{ }^{\prime}\right), 7.23(1 \mathrm{H}, \mathrm{t}, J=8.0 \mathrm{~Hz}, \mathrm{H}-4), 7.42$ $(2 \mathrm{H}, \mathrm{d}, J=8.0 \mathrm{~Hz}, \mathrm{H}-3$ and H-5), $7.66(1 \mathrm{H}, \mathrm{d}, J=16.0 \mathrm{~Hz}, \mathrm{H}-\alpha), 7.85(1 \mathrm{H}, \mathrm{d}, J=16.0 \mathrm{~Hz}, \mathrm{H}-\beta), 8.02(2 \mathrm{H}, \mathrm{d}, J=8.4$ $\mathrm{Hz}, \mathrm{H}-2^{\prime}$ and $\left.\mathrm{H}-6^{\prime}\right)$.

\section{2'-Hydroxy-2,6-dichlorochalcone (2)}

IR $\left(v \mathrm{~cm}^{-1}\right): 3435(-\mathrm{OH}), 1686(\mathrm{C}=\mathrm{O}), 1645(\mathrm{C}=\mathrm{C}$ alkene $), 1580$ and $1437(\mathrm{C}=\mathrm{C}$ aromatic $), 1307(\mathrm{C}-\mathrm{O})$ and 775 $(\mathrm{C}-\mathrm{Cl}) ;{ }^{1} \mathrm{H}$ NMR $\left(400 \mathrm{MHz}, \mathrm{CDCl}_{3}\right): \delta 6.96\left(1 \mathrm{H}, \mathrm{ddd}, J=2.0,8.0\right.$ and $\left.8.0 \mathrm{~Hz}, \mathrm{H}-5{ }^{\prime}\right), 7.08(1 \mathrm{H}, \mathrm{dd}, J=2.0$ and 8.0

$\left.\mathrm{Hz}, \mathrm{H}-3^{\prime}\right), 7.26(1 \mathrm{H}, \mathrm{dd}, J=8.0$ and $8.0 \mathrm{~Hz}, \mathrm{H}-4), 7.43(2 \mathrm{H}, \mathrm{d}, J=8.0 \mathrm{~Hz}, \mathrm{H}-3$ and $\mathrm{H}-5), 7.55(1 \mathrm{H}, \mathrm{ddd}, J=2.0,8.0$ and $\left.8.0 \mathrm{~Hz}, \mathrm{H}-4^{\prime}\right), 7.89\left(1 \mathrm{H}, \mathrm{dd}, J=2.0\right.$ and $\left.8.0 \mathrm{~Hz}, \mathrm{H}-6^{\prime}\right), 7.85(1 \mathrm{H}, \mathrm{d}, J=16.0 \mathrm{~Hz}, \mathrm{H}-\alpha), 8.00(1 \mathrm{H}, \mathrm{d}, J=16.0 \mathrm{~Hz}$, $\mathrm{H}-\beta)$, and $12.65(1 \mathrm{H}, \mathrm{s},-\mathrm{OH})$.

\section{2 '-Hydroxy-4-chlorochalcone (3)}

IR $\left(v \mathrm{~cm}^{-1}\right): 3446(-\mathrm{OH}), 1639(\mathrm{C}=\mathrm{O}), 1579(\mathrm{C}=\mathrm{C}$ alkene $), 1564$ and $1487(\mathrm{C}=\mathrm{C}$ aromatic $), 1205(\mathrm{C}-\mathrm{O}$ alcohol $)$ and $760(\mathrm{C}-\mathrm{Cl}) ;{ }^{1} \mathrm{H}$ NMR $\left(400 \mathrm{MHz}, \mathrm{CDCl}_{3}\right): \delta 6.98\left(1 \mathrm{H}\right.$, ddd, $J=1.6,8$ and $\left.8 \mathrm{~Hz}, \mathrm{H}-5^{\prime}\right), 7.06(1 \mathrm{H}, \mathrm{dd}, J=1.6$ and $\left.8 \mathrm{~Hz}, \mathrm{H}-3^{\prime}\right), 7.45(2 \mathrm{H}, \mathrm{d}, J=8 \mathrm{~Hz}, \mathrm{H}-3$ and $\mathrm{H}-5), 7.54\left(1 \mathrm{H}\right.$, ddd, $J=1.6,8$ and $\left.8 \mathrm{~Hz}, \mathrm{H}-4^{\prime}\right), 7.63(2 \mathrm{H}, \mathrm{d}, J=8 \mathrm{~Hz}$, $\mathrm{H}-2$ and H-6), $7.68(1 \mathrm{H}, \mathrm{d}, J=15.6 \mathrm{~Hz}, \mathrm{H}-\alpha), 8.00(1 \mathrm{H}, \mathrm{d}, J=15.6 \mathrm{~Hz}, \mathrm{H}-\beta), 7.95\left(1 \mathrm{H}, \mathrm{dd}, J=1.6 \mathrm{and} 8 \mathrm{~Hz}, \mathrm{H}-6^{\prime}\right)$ and $12.78(1 \mathrm{H}, \mathrm{s},-\mathrm{OH})$.

\section{2'-Hydroxy-4-nitrochalcone (4)}

IR $\left(v \mathrm{~cm}^{-1}\right): 3447(-\mathrm{OH}), 1704(\mathrm{C}=\mathrm{O}), 1645(\mathrm{C}=\mathrm{C}$ alkene), 1607 and $1442(\mathrm{C}=\mathrm{C}$ aromatic), 1541 and 1345( $\mathrm{N}=\mathrm{O}), 1197(\mathrm{C}-\mathrm{N})$ and $1104(\mathrm{C}-\mathrm{O}) ;{ }^{1} \mathrm{H} \mathrm{NMR}\left(400 \mathrm{MHz}, \mathrm{CDCl}_{3}\right): \delta 7.01(1 \mathrm{H}$, ddd, $J=1.6,8.0 \mathrm{and} 8.0 \mathrm{~Hz}, \mathrm{H}-$ $\left.5^{\prime}\right), 7.09\left(1 \mathrm{H}, \mathrm{dd}, J=1.6\right.$ and $\left.8.0 \mathrm{~Hz}, \mathrm{H}-3^{\prime}\right), 7.58\left(1 \mathrm{H}, \mathrm{ddd}, J=1.6,8.0\right.$ and $\left.8.0 \mathrm{~Hz}, \mathrm{H}-4^{\prime}\right), 7.79(1 \mathrm{H}, \mathrm{d}, J=15.6 \mathrm{~Hz}$, $\mathrm{H}-\alpha), 7.85(2 \mathrm{H}, \mathrm{d}, J=8.0 \mathrm{~Hz}, \mathrm{H}-2$ and H-6), $7.94(1 \mathrm{H}, \mathrm{d}, J=15.6 \mathrm{~Hz}, \mathrm{H}-\beta), 7.96(1 \mathrm{H}, \mathrm{dd}, J=1.6 \mathrm{and} 8.0 \mathrm{~Hz}, \mathrm{H}-$ $\left.6^{\prime}\right), 8.32(2 \mathrm{H}, \mathrm{d}, J=8.0 \mathrm{~Hz}, \mathrm{H}-3$ and $\mathrm{H}-5)$, and $12.62(1 \mathrm{H}, \mathrm{s},-\mathrm{OH})$.

\section{2'-Hydroxy-4-(dimethyl)aminochalcone (5)}

IR $\left(v \mathrm{~cm}^{-1}\right): 3435(-\mathrm{OH}), 2919\left(\mathrm{C}-\mathrm{H} \mathrm{sp} p^{3}\right), 1622(\mathrm{C}=\mathrm{O}), 1599(\mathrm{C}=\mathrm{C}$ alkene $), 1520$ and $1487(\mathrm{C}=\mathrm{C}$ aromatic $), 1177$ $(\mathrm{C}-\mathrm{O})$ and $1035(\mathrm{C}-\mathrm{N}) ;{ }^{1} \mathrm{H}$ NMR $\left(400 \mathrm{MHz}, \mathrm{CDCl}_{3}\right): \delta 3.09\left(6 \mathrm{H}, \mathrm{s}, 2 \mathrm{x} \mathrm{CH}_{3}\right), 6.74(2 \mathrm{H}, \mathrm{d}, J=8.8 \mathrm{~Hz}, \mathrm{H}-3$ and $\mathrm{H}-5), 6.95(1 \mathrm{H}$, ddd, $J=1.6,8.0$ and $8.0 \mathrm{~Hz}, \mathrm{H}-5$ '), $7.03(1 \mathrm{H}, \mathrm{dd}, J=1.6$ and $8.0 \mathrm{~Hz}, \mathrm{H}-3$ ') 7.47 (1H, ddd, $J=1.6$, 8.0 and $8.0 \mathrm{~Hz}, \mathrm{H}-4$ ') $7.52(1 \mathrm{H}, \mathrm{d}, J=16.0, \mathrm{H}-\alpha), 7.62(2 \mathrm{H}, \mathrm{d}, J=8.8 \mathrm{~Hz}, \mathrm{H}-2$ and $\mathrm{H}-6), 7.93(1 \mathrm{H}, \mathrm{d}, J=16.0 \mathrm{~Hz}$, $\mathrm{H}-\beta), 7.95(1 \mathrm{H}, \mathrm{dd}, J=1.6$ and $8.0 \mathrm{~Hz}, \mathrm{H}-6$ '), and $13.23(1 \mathrm{H}, \mathrm{s},-\mathrm{OH})$. 


\section{2'-Hydroxy-4-methoxychalcone (6)}

IR $\left(v \mathrm{~cm}^{-1}\right): 3422(-\mathrm{OH}), 1688(\mathrm{C}=\mathrm{O}), 1622(\mathrm{C}=\mathrm{C}$ alkene $), 1623$ and $1462(\mathrm{C}=\mathrm{C}$ aromatic $)$ and $1134(\mathrm{C}-\mathrm{O}) ;{ }^{1} \mathrm{H}$ $\operatorname{NMR}\left(400 \mathrm{MHz}, \mathrm{CDCl}_{3}\right): \delta 3.89\left(3 \mathrm{H}, \mathrm{s}, \mathrm{OCH}_{3}\right), 6.94\left(1 \mathrm{H}, \mathrm{ddd}, J=1.6,8.0\right.$ and $\left.8.0 \mathrm{~Hz}, \mathrm{H}-4^{\prime}\right), 6.97(2 \mathrm{H}, \mathrm{d}, J=8.8$ $\mathrm{Hz}, \mathrm{H}-3$ and $\mathrm{H}-5), 7.03\left(1 \mathrm{H}, \mathrm{dd}, J=2.0\right.$ and $\left.8.0 \mathrm{~Hz}, \mathrm{H}-3^{\prime}\right), 7.49\left(1 \mathrm{H}, \mathrm{ddd}, J=1.6,8.0\right.$ and $\left.8.0 \mathrm{~Hz}, \mathrm{H}-5^{\prime}\right), 7.56(1 \mathrm{H}$, $\mathrm{d}, J=15.2, \mathrm{H}-\alpha), 7.65(2 \mathrm{H}, \mathrm{d}, J=8.8 \mathrm{~Hz}, \mathrm{H}-2$ and $\mathrm{H}-6), 7.91(1 \mathrm{H}, \mathrm{d}, J=15.2 \mathrm{~Hz}, \mathrm{H}-\beta), 7.94(1 \mathrm{H}, \mathrm{dd}, J=2.0$ and $\left.8.0 \mathrm{~Hz}, \mathrm{H}-6^{\prime}\right)$ and $12.97(1 \mathrm{H}, \mathrm{s},-\mathrm{OH})$.

2'-Hydroxy-4-O-prenyl-2,6-dichlorochalcone (7)

IR $\left(v \mathrm{~cm}^{-1}\right): 3445(-\mathrm{OH}), 3098\left(\mathrm{C}-\mathrm{H} s p^{2}\right), 2952\left(\mathrm{C}-\mathrm{H} s p^{3}\right), 1644(\mathrm{C}=\mathrm{O}), 1598(\mathrm{C}=\mathrm{C}$ alkene $), 1506$ and 1467 $\left(\mathrm{C}=\mathrm{C}\right.$ aromatic), $1232(\mathrm{C}-\mathrm{O})$ and $777(\mathrm{C}-\mathrm{Cl}) ;{ }^{1} \mathrm{H}$ NMR $\left(400 \mathrm{MHz}, \mathrm{CDCl}_{3}\right): \delta 1.78\left(3 \mathrm{H}, \mathrm{s}, \mathrm{H}-4^{\prime \prime}\right), 1.83(3 \mathrm{H}, \mathrm{s}, \mathrm{H}-$ $\left.5^{\prime \prime}\right), 4.58\left(2 \mathrm{H}, \mathrm{d}, J=6.8 \mathrm{~Hz}, \mathrm{H}-1^{\prime \prime}\right), 5.48\left(1 \mathrm{H}, \mathrm{t}, J=6.8 \mathrm{~Hz}, \mathrm{H}-2^{\prime \prime}\right), 6.50\left(1 \mathrm{H}, \mathrm{d}, J=2.4\right.$ and $\left.8.8 \mathrm{~Hz}, \mathrm{H}-5^{\prime}\right), 6.52(1 \mathrm{H}$, d, $\left.J=2.4 \mathrm{~Hz}, \mathrm{H}-3^{\prime}\right), 7.22(1 \mathrm{H}, \mathrm{dd}, J=8.0$ and $8.0 \mathrm{~Hz}, \mathrm{H}-4), 7.41(2 \mathrm{H}, \mathrm{d}, J=8.0 \mathrm{~Hz}, \mathrm{H}-3$ and $\mathrm{H}-5), 7.76(1 \mathrm{H}, \mathrm{d}$, $\left.J=8.8 \mathrm{~Hz}, \mathrm{H}-6^{\prime}\right), 7.79(1 \mathrm{H}, \mathrm{d}, J=15.6, \mathrm{H}-\alpha), 7.94(1 \mathrm{H}, \mathrm{d}, J=15.6 \mathrm{~Hz}, \mathrm{H}-\beta)$ and $13.27(1 \mathrm{H}, \mathrm{s},-\mathrm{OH})$.

$2^{\prime}, 6^{\prime}$-Dichloroflavone (8)

IR $\left(v \mathrm{~cm}^{-1}\right): 1686(\mathrm{C}=\mathrm{O}), 1645(\mathrm{C}=\mathrm{C}$ alkene $), 1681$ and $1438(\mathrm{C}=\mathrm{C}$ aromatic $), 1311(\mathrm{C}-\mathrm{O})$ and $776(\mathrm{C}-\mathrm{Cl}) ;{ }^{1} \mathrm{H}$ $\operatorname{NMR}\left(400 \mathrm{MHz}, \mathrm{CDCl}_{3}\right): \delta 6.42(1 \mathrm{H}, \mathrm{s}, \mathrm{H}-3), 7.29(1 \mathrm{H}, \mathrm{dd}, J=1.6$ and $8.0 \mathrm{~Hz}, \mathrm{H}-3), 7.42\left(2 \mathrm{H}, \mathrm{d}, J=8.0 \mathrm{~Hz}, \mathrm{H}-3^{\prime}\right.$ and $\left.\mathrm{H}-5^{\prime}\right), 7.46(1 \mathrm{H}$, ddd, $J=2.0,8.0$ and $8.0 \mathrm{~Hz}, \mathrm{H}-5), 7.55\left(1 \mathrm{H}, \mathrm{dd}, J=8.0\right.$ and $\left.8.0 \mathrm{~Hz}, \mathrm{H}-4^{\prime}\right), 7.73(1 \mathrm{H}$, ddd, $J=2.0,8.0$ and $8.0 \mathrm{~Hz}, \mathrm{H}-4)$ and $8.32(1 \mathrm{H}, \mathrm{dd}, J=1.6$ and $8.0 \mathrm{~Hz}, \mathrm{H}-6)$.

2',6'-dichloroflavanone (9)

IR $\left(v \mathrm{~cm}^{-1}\right): 2863\left(\mathrm{C}-\mathrm{H} s p^{3}\right), 1693(\mathrm{C}=\mathrm{O}), 1610$ and $1463\left(\mathrm{C}=\mathrm{C}\right.$ aromatic), $1283(\mathrm{C}-\mathrm{O})$ and $762(\mathrm{C}-\mathrm{Cl}) ;{ }^{1} \mathrm{H}$ NMR $\left(400 \mathrm{MHz}, \mathrm{CDCl}_{3}\right): \delta 3.60(1 \mathrm{H}, \mathrm{dd}, J=2.4$ and $12.8 \mathrm{~Hz}$, vicinal $\mathrm{H}-2), 5.49(1 \mathrm{H}, \mathrm{dd}, J=2.4$ and $15.6 \mathrm{~Hz}$, geminal $\mathrm{H}-3 \mathrm{a}), 6.09(1 \mathrm{H}, \mathrm{dd}, J=12.8$ and $15.6 \mathrm{~Hz}$, geminal $\mathrm{H}-3 \mathrm{~b}), 7.06(1 \mathrm{H}, \mathrm{dd}, J=1.6$ and $8 \mathrm{~Hz}, \mathrm{H}-3), 7.12(1 \mathrm{H}, \mathrm{ddd}$, $J=1.6,8$ and $8 \mathrm{~Hz}, \mathrm{H}-5), 7.29\left(1 \mathrm{H}, \mathrm{dd}, J=8.0\right.$ and $\left.8.0 \mathrm{~Hz}, \mathrm{H}-4^{\prime}\right), 7.43\left(2 \mathrm{H}, \mathrm{d}, J=8.0 \mathrm{~Hz}, \mathrm{H}-3^{\prime}\right.$ and $\left.\mathrm{H}-5^{\prime}\right), 7.57(1 \mathrm{H}$, ddd, $J=1.6,8.0$ and $8.0 \mathrm{~Hz}, \mathrm{H}-4)$ and $7.951 \mathrm{H}$, dd, $J=1.6$ and $8.0 \mathrm{~Hz}, \mathrm{H}-6)$.

\section{ANTIMICROBIAL ACTIVITY}

\section{Test Microorganism}

For bacteria; Bacillus cereus (ATCC11778), Enterococcus faecalis (ATCC19433) (Gram-positive), Kleibsiella pneumonia (ATCC13883) and Pseudomonas aeroginosa (ATCC9027) (Gram-negative) and two fungi; Aspergillus fumigatus (ATCC204305) and Candida glabrata (ATCC2001) were purchased from Mutiara Scientific, Cheras, Kuala Lumpur, Malaysia. The strains were grown on nutrient agar (NA) (Oxoid, Italy) for the bacteria, and sabouraud dextrose agar (SDA) for fungi.

\section{Disc diffusion}

Antimicrobial activity of the chalcones, flavone and flavanone were determined by [13, 14]. The suspension $(400 \mu \mathrm{L})$ of the test bacteria and fungi were spread on the nutrient agar (NA) and sabouraud dextrose agar (SDA) respectively. The disc $(6 \mathrm{~mm}$ diameter) impregnated with $10 \mu \mathrm{L}$ of the target compounds and DMSO (negative control) was placed on the inoculated agar, which was incubated for $24 \mathrm{~h}$ at $37^{\circ} \mathrm{C}$ (for bacteria) and 48 $\mathrm{h}$ at $30^{\circ} \mathrm{C}$ (for fungi). Streptomycin sulfate $(10 \mu \mathrm{g} / \mathrm{mL}$ ) and nystatin (100 IU) were used as the positive controls for bacteria and fungi respectively. Clear inhibition zones around the discs indicated the presence of antimicrobial activity. All tests and analyses were carried out in triplicate and recorded.

\section{Minimum inhibitory concentration (MIC)}

The MIC was determined by the broth micro dilution method using 96-well micro-plates [13, 14]. The inoculate of the microbial strains was prepared from $24 \mathrm{~h}$ broth cultures and suspensions were adjusted to 0.5 McFarland standard turbidity. Each sample $(1.0 \mathrm{mg})$ was dissolved in DMSO $(1 \mathrm{~mL})$ to obtain $1000 \mu \mathrm{g} / \mathrm{mL}$ stock solution. A number of wells were reserved in each plate for positive and negative controls. Sterile broth $(100 \mu \mathrm{L})$ was added to the well from row B to $\mathrm{H}$. The stock solutions of samples $(100 \mu \mathrm{L})$ were added to the wells in rows $\mathrm{A}$ and $\mathrm{B}$. Then, the mixture of samples and sterile broth $(100 \mu \mathrm{L})$ in row B was transferred to each well in order to obtain a twofold serial dilution of the stock samples (concentration of 1000,500, 250, 125, 62.5, 31.3, 15.6 and $7.8 \mu \mathrm{g} / \mathrm{mL})$. The inoculums $(100 \mu \mathrm{L})$ were added to each well and a final volume $200 \mu \mathrm{L}$ was obtained in each well. Streptomycin sulfate for bacteria and nystatin for fungi were used as positive controls. Plates were incubated at $37^{\circ} \mathrm{C}$ for $24 \mathrm{~h}$. Microbial growth was indicated by the presence of turbidity and a pellet at the bottom of the well as shown in. 
Chemistry

\section{Results And Discussion}

The synthetic approach to the targeted compounds was illustrated in scheme 1. A mixture of substituted acetophenone and substituted aromatic aldehyde was stirred in ethanol and then sodium hydroxide solution was added drop wise until a highly turbid solution is obtained. The mixture was kept overnight at room temperature and it was poured on crush ice and acidified with dilute hydrochloric acid yielded substituted chalcone. Furthermore, the flavone was obtained by cyclisation in the presence of iodine in DMSO as catalyst at room temperature while the flavanone was obtained using $\mathrm{NaOAc}$ in $\mathrm{MeOH}$. The structures of the compounds (1-9) were ascertained by spectral parameters (IR and NMR) as well as the physical data which were recorded in Table I. Among the chalcones, compound 1 displayed higher percentage yield followed by compound 5, 4, 7, 3, 2 and 6. This is probably due to the purification techniques employed as compounds $\mathbf{1}, \mathbf{5}$ and $\mathbf{4}$ were purified by recrystallization technique using appropriate solvent while compounds $\mathbf{7}, \mathbf{3}, \mathbf{2}$ and $\mathbf{6}$ were purified by column chromatographic technique. The IR spectrum of 2'-hydroxy-2,6-dichlorochalcone (2) showed broad stretching band at $3435 \mathrm{~cm}^{-1}$ attributed to chelated $-\mathrm{OH}$ together with a strong stretching absorptions of $\mathrm{C}=\mathrm{O}$ and $\mathrm{C}=\mathrm{C}$ alkene at $1686 \mathrm{~cm}^{-1}$ and $1645 \mathrm{~cm}^{-1}$ respectively. The stretching absorptions at $1580 \mathrm{~cm}^{-1}$ and $1437 \mathrm{~cm}^{-1}$ were ascribed to the $\mathrm{C}=\mathrm{C}$ aromatic, followed by the $\mathrm{C}-\mathrm{O}$ alcohol absorption at $1307 \mathrm{~cm}^{-1}$. The absorption band for $\mathrm{C}$ $\mathrm{Cl}$ was observed at $775 \mathrm{~cm}^{-1}$. The ${ }^{1} \mathrm{H}$ NMR spectra displayed the presence of two sets of doublet signals each resonated at $\delta 7.85(1 \mathrm{H}, \mathrm{d}, J=16 \mathrm{~Hz})$, and $8.00(1 \mathrm{H}, \mathrm{d}, J=16 \mathrm{~Hz})$ corresponding to two trans-coupled olefinic protons, $\mathrm{H}-\alpha$ and $\mathrm{H}-\beta$. This proved that condensation of 2-hydroxyacetophenone and 2,6-dichlorobenzaldehyde had successfully occurred. The ${ }^{1} \mathrm{H}$ NMR also showed the resonance of aromatic ring A protons at $\delta 6.96(1 \mathrm{H}$, ddd, $J=2,8$ and $8 \mathrm{~Hz}), 7.08(1 \mathrm{H}, \mathrm{dd}, J=2$ and $8 \mathrm{~Hz}), 7.55(1 \mathrm{H}$, ddd, $J=2,8$ and $8 \mathrm{~Hz})$, and $7.89(1 \mathrm{H}, \mathrm{dd}, J=1.6$ and $8 \mathrm{~Hz}$ ) corresponding to $\mathrm{H}-5$ ', $\mathrm{H}-3$ ', $\mathrm{H}-4$ ', and $\mathrm{H}-6$ ' respectively. The aromatic protons of ring $\mathrm{B}$ were also observed at $\delta 7.26(1 \mathrm{H}, \mathrm{dd}, J=8$ and $8 \mathrm{~Hz}), 7.43(2 \mathrm{H}, \mathrm{d}, J=8 \mathrm{~Hz})$ corresponding to $\mathrm{H}-4, \mathrm{H}-3$, and $\mathrm{H}-5$ respectively. Moreover, a downfield signal at $12.65(1 \mathrm{H}, \mathrm{s})$ corresponding to chelated $\mathrm{OH}$.

Table I: Physical data of the synthesized chalcones, flavone and flavanone.

\begin{tabular}{llllll}
\hline $\begin{array}{l}\text { Compound } \\
\text { Codes }\end{array}$ & $\begin{array}{l}\text { M.P. } \\
\left({ }^{\circ} \mathbf{C}\right)\end{array}$ & M.P. [Lit.] & $\begin{array}{l}\text { Yield } \\
(\%)\end{array}$ & $\begin{array}{l}\mathbf{R}_{\mathbf{f}} \\
\text { value }\end{array}$ & Color \\
1 & $124-126$ & $190-192[8]$ & 87.4 & 0.62 & Yellow \\
2 & $66-68$ & $68-70[5]$ & 62.1 & 0.79 & Yellow \\
3 & $144-146$ & $149-150[15]$ & 65.9 & 0.72 & Yellow \\
4 & $102-104$ & $104-106[5]$ & 75.1 & 0.81 & Yellow \\
5 & $58-60$ & $55[16]$ & 76.0 & 0.59 & Orange \\
6 & $86-90$ & $92-93[17]$ & 61.8 & 0.60 & Yellow \\
7 & $96-98$ & $101-102[18]$ & 74.5 & 0.83 & Yellow \\
8 & $142-144$ & $144-146[19]$ & 64.9 & 0.75 & White \\
9 & $144-146$ & $148-149[20]$ & 56.9 & 0.60 & White \\
\hline
\end{tabular}

\section{Antimicrobial Activity}

All the targeted compounds were evaluated as antimicrobial agents against Bacillus cereus, Enterococcus faecalis, Kleibsiella pneumonia, Pseudomonas aeroginosa and antifungal activity against Aspergillus fumigatus and Candida glabrata. The compounds that showed positive activity were further tested using the minimum inhibitory concentration (MIC) to determine the concentration at which the compounds show higher activity. Among all the screened compounds, only compounds (3) and (4) displayed moderate activity against the Gram-positive bacteria producing a zone inhibition of 16 and $14 \mathrm{~mm}$ against E. faecalis and 12 and 12 $\mathrm{mm}$ against $B$. cereus respectively both with MIC $125 \mu \mathrm{g} / \mathrm{ml}$ as shown in Table II. Moreover, compounds (3) and (4) exhibited weak activity against the Gram-negative fungi each with 9 and $7 \mathrm{~mm}$ inhibition zone against $K$. pneumoniae and 7 and $8 \mathrm{~mm}$ against $P$. aeroginosa both with MIC of $500 \mu \mathrm{g} / \mathrm{ml}$. Compounds (1), (2), (7), (8) and (9) were inactive against all the tested microorganisms and their MIC results showed high turbidity at various concentrations justifying their inactivity. Compounds (3), (4), (5) and (6) showed very weak activity against $A$. fumigatus and $C$. glabrata with a very low zone of inhibition and high MIC compared to the standard control (Nystasin) as shown in Table II. A careful analysis of the data shows compounds with $-\mathrm{OCH}_{3}$ group incorporated causes loss of activity [15]. Moreover, even though the $\alpha, \beta$-unsaturated carbonyl group is found to be responsible for the antimicrobial activity [15], compounds with more than one electron withdrawing group such as chlorine atom on ring B of the chalcone skeleton causes loss of antimicrobial activity. The detail antimicrobial activities of the target compounds are recorded in Table II. 
Table II: Zone inhibition and Minimum inhibitory concentration (MIC) of the synthesized compounds.

\begin{tabular}{|c|c|c|c|c|c|c|c|}
\hline \multirow{2}{*}{$\begin{array}{l}\text { Cmpd } \\
\text { codes } \\
\end{array}$} & \multirow[t]{2}{*}{ Assay } & \multicolumn{3}{|c|}{ Antibacterial } & \multicolumn{3}{|c|}{ Antifungal } \\
\hline & & E.f. & B.s. & K.p. & P.a. & A.f. & C.g. \\
\hline \multirow[t]{2}{*}{1} & DD & - & - & - & - & - & - \\
\hline & MIC & - & - & - & - & - & - \\
\hline \multirow[t]{2}{*}{2} & DD & - & - & - & - & - & - \\
\hline & MIC & - & - & - & - & - & - \\
\hline \multirow[t]{2}{*}{3} & DD & $16 \pm 0.50$ & $12 \pm 0.46$ & $9 \pm 0$ & $7 \pm 0.52$ & $6 \pm 0$ & $6 \pm 0.43$ \\
\hline & MIC & 125 & 125 & 500 & 500 & 250 & 250 \\
\hline \multirow[t]{2}{*}{4} & DD & $14 \pm 0.53$ & $12 \pm 0.55$ & $7 \pm 0.40$ & $8 \pm 0.22$ & $7 \pm 0.43$ & $6 \pm 0.45$ \\
\hline & MIC & 125 & 125 & 500 & 500 & 250 & 250 \\
\hline \multirow[t]{2}{*}{5} & DD & $9 \pm 0$ & $7 \pm 0.42$ & $6 \pm 0.12$ & $7 \pm 0$ & $6 \pm 0.40$ & $6 \pm 0.32$ \\
\hline & MIC & 300 & 300 & 500 & $>500$ & $>500$ & $>500$ \\
\hline \multirow[t]{2}{*}{6} & DD & $8 \pm 0.43$ & $8 \pm 0.45$ & $6 \pm 0.42$ & $8 \pm 0.43$ & $6 \pm 0$ & $7 \pm 0.21$ \\
\hline & MIC & 350 & 300 & 350 & 350 & $>500$ & 350 \\
\hline \multirow[t]{2}{*}{7} & DD & - & - & - & - & - & - \\
\hline & MIC & - & - & - & - & - & - \\
\hline \multirow[t]{2}{*}{8} & DD & - & - & - & - & - & - \\
\hline & MIC & - & - & - & - & - & - \\
\hline \multirow[t]{2}{*}{9} & DD & - & - & - & - & - & - \\
\hline & MIC & - & - & - & - & - & - \\
\hline \multirow[t]{2}{*}{ SS } & DD & $24 \pm 0$ & $22 \pm 0$ & $24 \pm 0$ & $26 \pm 0$ & & \\
\hline & MIC & 7.8 & 7.8 & 7.8 & 7.8 & & \\
\hline \multirow[t]{2}{*}{ NS } & DD & & & & & $17 \pm 0$ & $17 \pm 0$ \\
\hline & MIC & & & & & 15.6 & 15.6 \\
\hline
\end{tabular}

Zone of inhibition measured in mm: Enterococcus faecalis (E.f.), Bacillus cereus (B.s), Kleibsiella pneumonia (K.p.), Pseudomonas aeroginosa (P.a.), Aspergillus fumigatus (A.f.) and Candida glabrata (C.g.)

SS: Streptomycin Sulfate, NS: Nystatin

-: No activity; result are means of three replicates. Diameter of the well $(6 \mathrm{~mm})$

\section{Conclusion}

In the present work, a flavone, flavanone and a series of chalcones were successfully synthesized and characterized by spectral studies. All the synthesized compounds were evaluated for their antimicrobial activities against B. cereus, E. faecalis, K. pneumonia, P. aeroginosa, A. fumigatus and C. glabrata microorganisms by disc diffusion method. 2'-hydroxy-4-chlorochalcone (3) and 2'-hydroxy-4-nitrochalcone (4) showed moderate antimicrobial activity against the Gram positive bacteria with MIC $125 \mu \mathrm{g} / \mathrm{ml}$ and a very weak antifungal activity with MIC $250 \mu \mathrm{g} / \mathrm{ml}$. Other compounds were weakly active or completely inactive against all the tested microorganisms with a very low zone of inhibition and high MIC compared to the standard control and their MIC results showed high turbidity at various concentrations justifying their inactivity.

\section{Acknowledgement}

The Authors extends their appreciation to the Kano State Government for the scholarship and to the Department of Chemistry, Faculty of Science, Universiti Teknologi Malaysia for providing all the necessary equipments required for the research and funding the work through the research group Vote No. RJ130000. 7826.4F142.

\section{References}

[1]. Srinivasa MR, Kotesh J, Narukulla R and Duddeck H: Synthesis and spectroscopic characterization of some chromanochalcones and their dihydro derivatives. Archive of Organic Chemistry. 2004; (xiv):96-102.

[2]. Reddy CS and Nagaraj A: Synthesis and biological study of novel bis-chalcones, bis-thiazines and bis-pyrimidines. Journal of the Iranian Chemical Society. 2008; 5:262-267.

[3]. Hamdi N, Fischmeister C, Puerta MC and Valerga P: A rapid access to new coumarinyl chalcone and substituted chromeno[4,3c]pyrazol-4(1H)-ones and their antibacterial and DPPH radical scavenging activities. Medicinal Chemistry Research. 2010; 19:1-16.

[4]. Kamal A, Prabhakar S, Ramaiah MJ, Reddy PV, Reddy CR, Mallareddy A, Shankaraiah, Lakshmi, Narayan, Reddy TLN, Pushpavalli SNCVL and Pal-Bhadra M: Synthesis and anticancer activity of chalcone-pyrrolobenzodiazepine conjugates linked via 1,2,3-triazole ring side-armed with alkane spacers. European Journal of Medicinal Chemistry. 2011; 46:3820-3831. 
[5]. Niti GG, Rajput PR, Banewar VW and Raut AR: Synthesis and antimicrobial activity of some chalcones and flavones having 2Hydroxy acetophenone Moiety. International Journal of Pharma and Bio Science. 2012; 3(3):389-395.

[6]. Kutaiba IA, and Mohamed AM: Flavonoids: Chemistry, Biochemistry and Antioxidant activity. Journal of Pharmacy Research. 2012; 5(8):4013-4020.

[7]. Prashar H, Chawla A, Sharma AK and Kharb R: Chalcone as a versatile moiety for diverse pharmacological activities. International Journal of Pharmaceutical Sciences and Research. 2012; 3(7):1913-1927.

[8]. Bano S, Javed K, Ahmad S, Rathish IG, Singh S, Chaitanya M, Arunasree KM and Alam MS: Synthesis of some novel chalcones, flavanones and flavones and evaluation of their anti-inflammatory activity. European Journal of Medicinal Chemistry. 2013; 65:5159.

[9]. Dimmock JR, Kandepu NM, Hetherington M, Quail JW, Pugazhenthi U, Sudom AM, Chamankhah M, Rose P, Pass E, Allen TM., Halleran S, Szydlowski J, Mutus B, Tannous M, Manavathur EK, Myers TG, De Clercq E and Balzarini J: Cytotoxic Activities of Mannich Bases of Chalcones and Related Compounds. Journal of Medicinal Chemistry. 1998; 41:1014-1026.

[10]. Sugamoto K, Matsusita Y, Matsui K, Kurogi C and Matsui T: Synthesis and antibacterial activity of chalcones bearing prenyl or geranyl groups from Angelica keiskei. Tettrahedron. 2011; 67:5346-5359.

[11]. Huang W, Chien P, Yang C and Lee A: Novel synthesis of flavonoids of Scutellaria baicelensis GEORGI. Chemical and Pharmaceutical Bulletin. 2003; 51:339-340.

[12]. Sharma A, Anand N, Sharma R, Chaturvedi U, Khanna AK, Bhatia G and Tripathi RP: Synthesis of 5-aryl-6-cinnamoyl-7-methylflavanones as novel antioxidants and antihyperlipidemics. Journal of Enzyme Inhibition and Medicinal Chemistry. 2012; 27(2):21122.

[13]. Saini RK, Choudhary AS, Joshi YC and Joshi P: Solvent Free Synthesis of Chalcones and their Antibacterial Activities. E-Journal of Chemistry. 2005; 2(4):224-227.

[14]. Bhuiyan MMH, Hossain MI, Mahmud and Mohammad Al-Amin MM: Microwave-assisted Efficient Synthesis of Chalcones as Probes for Antimicrobial Activities. Chemistry Journal. 2011, 1(1), 21-28.

[15]. Kamboj RC, Arora R, Sharma G, Kumar D, Sharma C, Joshi R and Aneja KR: Eco-friendly synthesis and antimicrobial activity of chalcones. Der Pharma Chemica. 2010; 2(3):157-170.

[16]. Singh HP, Pandeya SN, Chauhan CS, Chandra, Shekhar and Sharma CS: Synthesis and pharmacological screening of some novel chalconyl derivatives of substituted phenyl semicarbazide. Medicinal Chemistry Research. 2011; 20:74-80.

[17]. Ahmed N, Ali H and van Lier JE: Silica gel supported InBr3 and InCl3: new catalysts for the facile and rapid oxidation of 2hydroxychalcones and flavanones to their corresponding flavones under solvent free conditions, Tetrahedron Letters. 2005; 46:253256.

[18]. Ohkatsu Y and Satoh T: Antioxidant and photo-antioxidant activities of chalcone derivatives. Journal of the Japan Petroleum Institute. 2008; 51(5):298-308.

[19]. Bombardelli E and Valenti P: Preparation of chalcones having antiproliferative activity. U.S., 2002, US 6423740 B1 20020723, 110 .

[20]. Kumar D, Patel G, Kumar A, Roy and Ram K: Ionic liquid catalyzed expeditious synthesis of 2-aryl-2,3-dihydroquinolin-4(1H)-ones and 2-aryl-2,3-dihydro-4H-chromen-4-ones under microwave irradiation. Journal of Heterocyclic Chemistry. 2009; 46(4):791-795. 